\title{
THE EFFECTS OF RESEARCH AND DEVELOPMENT INTENSITY ON MANAGERIAL COMPENSATION IN LARGE ORGANIZATIONS
}

\author{
George T. Milkovich \\ Barry Gerhart \\ John Hannon
}

Working Paper \#90-09

\author{
393 Ives Hall \\ Center for Advanced Human Resource Studies \\ School of Industrial and Labor Relations \\ Cornell University \\ Ithaca, NY 14851-0952 \\ (607) $255-4470$
}

March 1990

Journal of High Technology Management Research, forthcoming.

This paper has not undergone formal review or approval of the faculty of the ILR School. It is intended to make the results of Center research, conferences, and projects available to others interested in human resource management in preliminary form to encourage discussion and suggestions. 


\begin{abstract}
Agency theory, leading edge, and administrative/life cycle perspectives all predict that organizations having high levels of Research and Development (R\&D) intensity will follow different compensation strategies than organizations that are less R\&D intensive. Using data from 110 organizations over a 5 year period, and controlling for organization differences in employee and job characteristics, we found support for this general prediction. Specifically, high R\&D intensity organizations tended to have higher relative base pay, higher relative bonus pay, and greater relative eligibility for long-term incentive payments. We discuss the importance of further research into compensation decisions in R\&D intensive firms, particularly the effects of such decisions on firms' competitiveness.
\end{abstract}




\section{THE EFFECTS OF RESEARCH AND DEVELOPMENT INTENSITY}

\section{ON MANAGERIAL COMPENSATION IN LARGE ORGANIZATIONS}

A growing literature suggests that differences exist between the compensation of employees in research and development (R\&D) intensive (often called "high tech") firms compared to employees in other firms (Kanter, 1989; Schuster, 1987; Kleingartner \& Anderson, 1987; Balkin \& Gomez-Mejia, 1984, 1987). Consultant surveys report similar patterns of differences (Wyatt, 1989; Bradford Associates, 1988; Hay Group, 1986). In the major empirical work on the matter, Balkin and Gomez-Mejia's $(1984,1987)$ found, for example, that compensation managers in $R \& D$ intensive firms reported greater use of performance-contingent pay in the form of stock awards and bonuses for scientists and engineers than did their counterparts in other firms.

As Balkin and Gomez-Mejia $(1984,1987)$ recognized, their research served as a useful beginning point, but had some potential limitations. First, compensation was measured using self-reports from a single source in each firm (the person responsible for compensation management). The accuracy of these self-reports is open to question, especially in cases where the respondent is asked to provide an estimate of the firm's competitive position (e.g., on base pay) compared to other firms. ${ }^{2}$ Moreover, it is the actual compensation received by employees, rather than the perceptions of compensation administrators, that is most likely to have an impact on employee attitudes, behaviors, and organization effectiveness. Second, their research focused exclusively on scientists and engineers (and only those in $R \& D$ units). It would be useful to know whether the practices applied to this key group of employees (in R\&D intensive firms) also sets the tone for compensation practices applied to other employees. Pressures for internal consistency or a corporate culture dominated by $R \& D$ personnel might contribute to this 
type of spillover. Third, the Balkin and Gomez-Mejia research used only firms within a 70 mile radius of the Boston "Route 128 technology center." It is unclear to what extent practices in such firms represent local versus national practices. A final problem with the Balkin and Gomez-Mejia (and consultant survey) findings is the lack of control of other factors that are likely to influence organization differences in compensation practices such as job (e.g., level) and individual (e.g., education, experience) characteristics.

Our study makes two contributions to the literature on compensation decisions and R\&D intensive firms. First, it uses a national sample to provide new evidence on differences between large $R \& D$ intensive and other firms in actual compensation outcomes for top- and mid- level managers. Our focus is on potential differences in base salaries, short-term bonus payments and long-term incentive eligibility practices. Second, aside from Balkin and Gomez-Mejia's work, much of literature tends to be descriptive, anecdotal, or speculative, offering only limited theoretical explanations for observed patterns of compensation differences. In contrast, we consider agency theory, leading edge, and administrative/life cycle explanations for why firms that emphasize R\&D would be expected to compensate managers differently.

\section{R\&D INTENSITY, HIGH TECH AND INNOVATION}

How do we recognize a high tech or $R \& D$ intensive organization when we see it? Writers on this topic often use concepts such as high tech, R\&D intensive, and innovative interchangeably when describing organizations. Briefly stated, high technology organizations have been defined as those that exhibit some combination of the following characteristics. They emphasize inventions and innovation in their business strategies, deploy a significant percentage of their financial resources to R\&D, employ a relatively 
high percentage of scientists and engineers in the work force, or compete in worldwide, short-life cycle markets (BLS, 1982; Kleingartner \& Anderson, 1987; Balkin \& GomezMejia, 1987). The BLS definition of high tech industries includes electronic components, communications equipment, guided missile and space, aircraft, drugs, biotechnology, and information technology firms (BLS, 1982). Consultants seem to define high tech according to their clients' needs. Thus, Wyatt's ECS High Tech Industry Group (1989) includes aerospace, electronics, semi conductors, telecommunications instruments, biomedical equipment, computers, and office equipment firms.

$R \& D$ intensity generally refers to the extent to which resources, financial and human, are devoted to R\&D (Gambino and Gartenberg, 1979). Bound, Cummins, Griliches, Hall, and Jaffe (1985) note that the R\&D expenditures must be reported on the 10-K form when they are "material" or "exceeded one percent of sales." Research typically treats $R \& D$ intensity as a continuous variable measured as: (1) the ratio of $R \& D$ expenditures to sales, (2) $R \& D$ expenditures per employee, (3) the level of $R \& D$ expenditures, (4) the number of patents applied for or, granted and so on (Griliches, 1986).

Innovation, according to Acs and Audretsch (1988), is a process that begins with an invention, proceeds with the development of that invention, and results in the introduction of a new or modified product, process, or service in the market. They see R\&D expenditures as an input into the innovative process.

However, nuances and complexities quickly become apparent in using these definitions. For example, Galbraith (1982) distinguishes between invention (creating new ideas) and innovation (transforming the idea into a process or product). He prescribes different organizational systems for innovative and operational (manufacturing) 
organizations. Current wisdom in the business press is that firms achieve competitive advantage by shortening the time from invention to market through the use of product teams comprised of $\mathrm{R} \& \mathrm{D}$, marketing, and manufacturing personnel (Business Week Innovation, 1989). In a related development, Scarpello, Boulton, and Hofer (1986) see three roles for R\&D as part of a business strategy: (1) developing new products ahead of competitors, (2) improving product quality, or (3) improving manufacturing processes.

Further complexities arise when we consider almost any large corporation. Some business units within the firm may be more $R \& D$ intensive, high tech, and/or innovative than others. GE, for example, includes NBC, financial services (Kidder Peabody), and space and defense divisions (GE Aerospace). Does it make sense to classify GE as high tech, $R \& D$ intensive, or innovative? Does it fall into one, two, or all three of these categories?

In the present paper, we have chosen to focus on R\&D intensity, a concept that has received a good deal of focus in the literature (e.g., Balkin \& Gomez-Mejia, 1984, 1987). Because there is no consensus in the literature on one best way to measure $R \& D$ intensity, we examine three measures: total $R \& D$ expenditures, $R \& D$ expenditures/employees, and R\&D expenditures/sales. ${ }^{3}$

\section{R\&D'S EFFECTS ON MANAGERIAL COMPENSATION}

Why would we expect to find differences in the compensation of managers in $R \& D$ intensive firms compared to their counterparts in other firms? We consider three potential explanations for a link between compensation practices and $R \& D$ intensity: the leading edge premise, administrative/life-cycle prescriptions, and agency theory. 
The leading edge premise is that innovations in personnel policies match the technological innovations that characterize these firms. If $R \& D$ (and high tech) is the next frontier of the industrial revolution and the basis on which future competitive advantage is to be achieved, then the personnel and compensation practices of these firms are also likely to be leading edge in nature (Balkin \& Gomez-Mejia, 1984). This argument that certain organizations, in this case R\&D firms, lead and others follow their behaviors is consistent with notions of patterns or wage contours described by Dunlop (1957) and the institutional theory ideas emerging in organization theory (Scott, 1986). In the domain of compensation, it would suggest that certain compensation approaches, such as performance contingent pay, would be more likely to occur in $R \& D$ units because innovation is endemic to these organizations and such pay practices are considered innovative.

Prescriptions in the administrative and strategic literature explain the R\&D intensity effect on managerial compensation in terms of product or organization life cycles, and cash flow demands. Cook (1976) was one of the earliest to argue that firms in startup and growth stages of their product life cycles face strong cash demands to finance capital expansion. They also have an external resource focus, based on the need to attract key technical contributors. Thus, Cook (1976), followed by Ellig (1981) and others, advised startup and growth firms to emphasize stock options and variable short-term pay increases in lieu of higher base pay as a means of conserving cash for investment and growth. Consistent with these ideas, recent strategic perspectives toward compensation (Milkovich, 1988; Gomez-Mejia \& Welborne, 1988), building on contingency models, hypothesize that the greater the congruency between an organization's external environment, culture, internal conditions, and its compensation decisions, the more effective it will be. 
The Balkin and Gomez-Mejia $(1984,1987)$ research described earlier has provided the most complete empirical test of the administrative/life cycle predictions. In the 1984 study, findings were somewhat mixed. Although, the reported use of contingent or variable pay was indeed greater in R\&D intensive firms than in other firms, so too were reported base salary levels. Similarly, although growth stage firms reported greater use of variable pay, they also reported higher base pay levels as well.

In the 1987 study, however, Balkin and Gomez-Mejia re-examined these issues (and some new ones) using compensation variables that were re-defined in terms of their relative importance in the pay mix. (Each component was reported as a percentage of total compensation.) With these re-defined compensation dependent variables, they found strong support for most of the key hypotheses. For example, variable pay was found to represent a greater proportion of compensation in both R\&D intensive and growth stage firms. They also found that both benefits and base salary accounted for smaller proportions of total compensation in these types of firms, consistent with the idea that one of their important goals is to minimize fixed costs. In addition, they found the positive relation between R\&D intensity and variable pay to be strongest in small firms and growth stage firms.

Despite this apparent support for the life cycle perspective, it is important to recognize that the external validity of these findings remains open to question. Aside from the potential limitations mentioned earlier, note that the majority of Balkin and GomezMejia's sample was composed of firms with fewer than 500 employees. Only 9 firms had over 5000 employees. One criticism of the product life cycle approach is that it's logic seems to break down when applied to larger, multi-product firms (Milkovich, 1988; Kerr, 
1987). For example, large R\&D intensive firms such as Merck and Digital Equipment are not cash poor. Thus, we would not necessarily expect as much concern with reducing fixed costs and preserving scarce cash resources for investment. Moreover, larger firms typically have multiple product lines, some of which may be in the growth stage, some of which may be in the mature stage, meaning that classifications in terms of product life cycle may be of questionnable validity.

Agency theory (Eisenhardt, 1988, 1989; Fama, 1980; Jensen \& Meckling, 1976) offers another theoretical explanation for the R\&D effect. Essentially, it is based on the assumption that the separation of ownership (principals) from control (agents or managers) in publicly held corporations results in an asymmetry of information between owners and managers. Managers in large R\&D firms hold information about their technical abilities and behaviors that is not available to the owners or requires significant costs for owners to monitor. The theory assumes that managers and owners act in their own best interests. Thus, for example, outcome based compensation (e.g., performance contingent bonus and stock plans) is offered to increase the likelihood that managers will act in the best interest of the owners. Under such plans, payouts to managers depend on objective outcomes such as ROE, ROA, or changes in shareholder wealth.

The agency theory explanation of the $R \& D$ effect is based on the premise that $R \& D$ intensive firms are subject to an exacerbation of the owner-manager information asymmetry. R\&D managers have greater access to significant technical, new product, or service information which can be implemented in their current firm or another one--such as a new venture started by the few key managers who leave. Compared to less $R \& D$ intensive firms, behavioral monitoring and collection of such technical data in the R\&D firm would 
be more costly (if not impossible) than measuring outcomes. Thus, the logic goes, managers' behavior and information cannot be as readily observed or controlled in R\&D firms due to the very nature of the innovative process. $R \& D$ inputs at one time period may not show readily observable results for several periods (Ruch, 1980; Beardsley, 1974). Furthermore, some interim performance measures in use are misguided (Brown and Swenson, 1988). Such indexes as patents applied for, publications, and meeting deadlines suffer because engineers are unlikely to publish (Allen, 1977), firms are less and less likely to patent in preference to holding the information proprietary (Bound et al., 1985), and meeting time deadlines is open to interpretation (Ruch, 1980).

Thus, according to agency theory, large R\&D intensive firms are more likely than others to (1) position their base pay above competitors to first attract the necessary talent and to retain their technical ideas and potential innovations, (2) make use of higher ratios of bonus to base pay to focus managers' decisions on outcomes rather than bear the costs of monitoring managers' interim behaviors, and (3) have greater eligibility of managers for long-term incentives which provide managers with incentives to remain and implement their ideas. $^{4}$

It should be kept in mind that R\&D intensity is only one of several factors that may influence compensation decisions (see Gerhart \& Milkovich, 1989, for a review). Dyer and Holder's (1989) strategic perspective suggests that three prototypical human resource strategies can be conceived: (1) inducers, in which compensation is used to induce desired behaviors (high base pay, emphasis on incentives), (2) investors, in which compensation plays a subordinate role to employment security, training, and employee assistance programs (meet competitors' base pay, greater emphasis on merit rather than 
bonus and long-term incentives), and (3) involvers, in which firms emphasize participation, teams, and sharing gains (emphasis on performance based bonuses). Note that greater emphasis on performance contingent pay is prescribed under both inducer and involver strategies. Dyer and Holder propose that although certain fits between strategy and conditions may be more appropriate, any of the three strategic types may be observed under similar environmental and organization conditions. Consequently, enough management discretion may exist, even within $R \& D$ intensive firms, to choose from a variety of human resource and compensation strategies.

In summary, the leading edge, administrative/life-cycle, and agency theory perspectives all predict that the pattern of managerial compensation in R\&D intensive firms will exhibit greater bonus to base ratios and greater eligibility among managers for longterm incentives. Further, agency theory predicts that R\&D firms' base compensation will lead competitors, whereas the alternative models predict a policy of meeting competitors' base pay practices.

\section{METHOD}

\section{Sample}

The Center for Advanced Human Resource Studies (CAHRS) Managerial Compensation Data Base was used for this study. It includes data on over 200 firms for the period 1981-85. The data include compensation, employee, job, and organization characteristics provided by a large private consulting firm; corporate level financial data derived from COMPUSTAT; and corporate R\&D data from the NBER's R\&D master file for the period 1981-85 (Hall, Cummins, Laderman, \& Mundy, 1988). The number of firms for this study was reduced to 110 , to include only those for which compensation, financial, 
and R\&D data were present, and which had three or more firms in the same industry, broadly defined using the 2-digit Standard Industrial Classification (SIC) code. Data on at least 75 employees per firm were analyzed. Compensation and financial data were adjusted to 1980 dollars using the CPI. Jobs in the data base covered a broad range of managerial and $\mathrm{R} \& \mathrm{D}$ positions, including top $\mathrm{R} \& \mathrm{D}$ engineering managers, top applied and basic researchers, top developmental engineers, and project managers.

\section{Measures and Analysis}

The compensation, financial, and R\&D data were measured at the firm level.

Dependent Variables. Each of the three compensation variables described below was measured as an organization average, statistically adjusted for organization differences in human capital (including years of education, potential experience (age - years of experience - 6), firm tenure, job tenure, and squared terms for the tenure/experience measures). The compensation variables were also statistically adjusted for organization differences in two job characteristics, the number of reporting levels from the board of directors, and the number of management levels supervised. The purpose of these statistical adjustments was to eliminate differences in compensation between organizations stemming from differences in employee characteristics or levels of responsibility.

Base salary is the firm's mean base salary for its managerial employees (exclusive of short- and long-term bonuses) relative to the sample as of March 1 of the survey year. This variable is operationalized as a percent above or below the sample mean. Bonus as a percent of base is the firm's bonus to base ratio relative to the sample, operationalized in terms of percentage points above or below the sample mean. Long-term incentive eligibility is the firm's proportion of managers eligible for long-term incentives relative to 
the sample, operationalized as percentage points above or below the sample mean.

Independent Variables. Organization characteristics included the number of employees (Compustat \#29); net sales (Compustat Item \#12); income before extraordinary items and discontinued operations (Compustat Item \#16); and industry (the 2-digit Standard Industrial Classification (SIC) code for the firm).

As noted earlier, $R \& D$ intensity can be measured in several ways. We selected three measures frequently used in the literature. First, we used total R\&D Expenditures (Compustat item \#46). However, this measure is heavily influenced by firm size. Clearly, $R \& D$ intensive firms are often defined in terms of their relative expenditures on $R \& D$. Therefore, we also measured $R \& D$ intensity relative to size by using both $R \& D$ Expenditures/employees, and R\&D Expenditures/sales.

Although these measures control for firm size, they raise other issues. For example, R\&D/Sales, perhaps the most commonly used measure, suffers from sales variability within the innovation process. Firms with projects at the beginning of the innovation process (e.g., superconductivity, or AIDS drug research) would experience lower sales, and consequently higher $\mathrm{R} \& \mathrm{D} / \mathrm{Sales}$ than those with projects in midstream or entering the end of the process (e.g., semiconductors), which generate more revenues, even if both spent the same amount on R\&D relative to its potential value added. Scherer (1984) suggests using R\&D per employee to avoid this problem, and others suggest including the sheer magnitude of $R \& D$ expenditures.

The three $R \& D$ intensity measures were treated as continuous variables in our analysis. We also subgrouped firms on each measure into High $R \& D$, and Other categories. The conventional 5\% and above was used for the R\&D/Sales measure (BLS, 
1983; Business Week, 1989). Using the 5\% threshold resulted in 23 of the 110 firms being classified as R\&D Intensive. The top 23 firms on each of the other two measures were then also classified into the high $R \& D$ Intensity category for comparison purposes. In 1980 dollars, the threshold for high $R \& D$ Intensity based on $R \& D /$ mployee was $\$ 4,000$. Using the $R \& D / s a l e s$ measure, the cutoff was $\$ 130$ million.

As Exhibit 1 shows, only 10 of the 23 firms classified as high R\&D Intensity based on $\mathrm{R} \& \mathrm{D} / \mathrm{Sales}$ were also classified as high $\mathrm{R} \& \mathrm{D}$ Intensive using the other two measures. These comparisons demonstrate that the various $R \& D$ Intensity measures are not necessarily substitutes for one another, and therefore, it is useful to study multiple measures of R\&D Intensity.

Exhibit 2 contains a summary of the data (scaled in 1980 dollars) used in our analyses.

As noted previously, our approach was to first adjust each firm's compensation outcomes for human capital and job characteristics differences yielding an average residual (over individuals) for each organization for each year. These adjusted averages were taken as indicative of the organization's relative position regarding base, bonus/base, and longterm incentive eligibility in each year, controlling for employee and job differences (see Gerhart \& Milkovich, 1989 for more information on this method). The next step was to examine and compare the pattern of compensation decisions in High $\mathrm{R} \& \mathrm{D}$ Intensive versus other firms. Finally, we performed a series of multiple regressions for each of the three compensation outcomes to assess the unique contribution of $R \& D$ Intensity. 


\section{RESULTS}

Over the 1981 to 1985 period, each measure of R\&D Intensity displayed considerable stability $(r=.85, R \& D / S a l e s ; r=.86, R \& D / E m p l o y e e s ; r=.81$, total $R \& D$ expenditures). Similarly, two of the compensation variables, base salary $(r=.89)$ and long-term incentive eligibility $(r=.67)$, also displayed stability. This evidence of stability is important because it suggests that both $R \& D$ intensity and compensation practices are enduring characteristics of firms.

A partial exception to the general pattern of stability was found for the bonus/base pay ratio $(r=.40)$. This finding is not surprising, however, because the actual bonus payment in any given year may depend on a combination of individual, unit, and firm performance measures, all of which fluctuate from year to year. As one example, the correlation between return on assets measured in 1981 and 1985 was only .08 . Given this instability in firm (and probably other measures of) performance, a much more troubling finding would be high stability in bonus payments because bonus payments that do not change with changes in performance represent, in effect, entitlements and fixed costs, just like base pay.

Figures 1, 2, and 3 highlight the differences in compensation practices between High $R \& D$ Intensive firms and Others. Note that regardless of the $R \& D$ measure analyzed, R\&D intensive firms have greater base (e.g., R\&D/Sales: $\$ 75,561$ versus $\$ 67,810$ ), bonus/base ratios (e.g., R\&D/Sales: $21.7 \%$ versus $19.3 \%$ ), and long-term incentive eligibility (e.g., R\&D/Sales: $78.5 \%$ versus $57.3 \%$ ) than other firms. Recall also that these results have already been adjusted for human capital and job characteristics within each firm. In other words, even after accounting for similarities in employees and jobs, high 
R\&D intensity firms engage in different compensation practices. As such, our findings are consistent with the results based on perceptual data reported by Balkin and Gomez-Mejia $(1984,1987)$.

The next step is to determine if these $R \& D$ effects exist when controlling for other potential determinants of compensation differences. The regressions summarized in Exhibits 3, 4, and 5 explicitly control for sales, number of employees, income, and industry. Organization differences in employee and job characteristics are also controlled by virtue of the statistical adjustments discussed in the Method section. R\&D intensity has a significant positive effect on relative base salary, bonus/base, and long-term incentive eligibility using each measure of R\&D intensity, with only one exception (Total R\&D expenditures does not have a significant effect on bonus/base). Thus, in 8 of the 9 models (i.e., 3 R\&D Intensity measures by 3 forms of pay), R\&D has a significant positive effect on managerial pay practices. Although the variance explained is low in several cases, recall that the effects of other key compensation determinants (human capital and job characteristics) were removed prior to these analyses. Nevertheless, it is clear that there is much unexplained variability in firms' compensation practices.

The fact that high R\&D intensive firms place more emphasis on contingent pay is consistent with predictions based on the leading edge, administrative/life cycle, and agency theory perspectives. In contrast, although the finding of higher base pay is consistent with agency theory, it is not consistent with predictions derived from the other two perspectives. An important implication of our results is that even firms within the same industry may follow very different R\&D spending and compensation strategies, because industry controls do not eliminate the link between R\&D intensity and compensation outcomes. 
One concern, however, is that measuring industry at the 2-digit level is not sufficiently precise to justify the argument that we have really compared firms in the same industry. Therefore, we created a subsample that included only $\underline{3}$-digit industries (and only those that had a minimum of 3 firms). Exhibit 6 indicates that the more precise control for industry did not significantly reduce the R\&D intensity coefficient in either the base pay or bonus/base pay equation. Thus, any R\&D effect on these pay outcomes does not appear to be an industry effect. On the other hand, the R\&D intensity coefficient in the long-term incentive eligibility equation is substantially reduced when using the 3-digit industry controls. Although it is not clear why only the long-term incentive eligibility results would change, one possibility is that the simple yes/no nature of the measure is unable to accurately capture the full extent of variation within industries. If, for example, the actual value of long-term incentives were available, more variation would almost certainly be observed, increasing the likelihood of a significant relation with $R \& D$ intensity. ${ }^{5}$

Finally, to model the effects of R\&D strategy on compensation, we used the regressions summarized in Exhibits 3-5 to examine the changes in compensation resulting if a hypothetical average firm (e.g., $R \& D / S a l e s=3.1 \%, R \& D / E m p l o y e e=\$ 2,330$, and $R \& D$ $=\$ 83$ million) became a High $R \& D$ intensive firm $(R \& D / S a l e s=5 \%, R \& D / E m p l o y e e=$ $\$ 4,000$, and $R \& D=\$ 130$ million). The changes are substantial. For example, an increase in $\mathrm{R} \& \mathrm{D} /$ Sales from $3.1 \%$ to $5.0 \%$ increases the predicted salary from $\$ 69,835$ to $\$ 72,977$, the predicted bonus from $20 \%$ to $21.1 \%$ of base (or from $\$ 13,967$ to $\$ 15,398$ ), and the predicted long-term incentive eligibility from $60 \%$ to $66.7 \%$. 


\section{DISCUSSION}

Our study provides new evidence that $R \& D$ intensive firms differ from other firms in the pattern of their compensation practices. For instance, those in the high R\&D Intensity group (based on $\mathrm{R} \& \mathrm{D} / \mathrm{Sales}$ ) set their managers' base pay higher, offered greater bonuses (as a percentage of base), and made greater use of long-term incentives.

In terms of the theories reviewed earlier, these findings appear most consistent with agency theory, which predicts both higher base pay and greater emphasis on performance contingent pay. As discussed, higher levels of base pay may be necessary to attract top technical talent. Then, pay based on objective organization performance measures may be used because accurate assessments using other (more intermediate) measures of performance may be all the more difficult where highly technical products with long-term development horizons are concerned.

The findings provide less support for the leading edge and administrative/life cycle predictions. Although the latter, for example, predicts a high emphasis on performance contingent pay, it is not consistent with our finding of higher base pay in $R \& D$ intensive firms. It is possible, however, that the nature of our sample partly explains this lack of support. Because most of the firms included were large and established, cash flow is likely to be less of a concern than in the small, start-up firms of the type that composed the bulk of the sample used by Balkin and Gomez-Mejia $(1984,1987)$. These smaller or younger firms may indeed be less able to offer high base salaries because of the associated high fixed costs and demands on cash flow.

At a more general level, our finding that the relation between $R \& D$ and compensation is typically significant, even within industries, is consistent with the notion 
advanced by Gerhart and Milkovich (1989) that these compensation decisions exhibit strategic-like properties that may be more aligned with organization characteristics (e.g., R\&D strategy) rather than industry patterns. Further, even similar firms may simply differ in their philosophies about how to design compensation practices to maximize organization effectiveness. Some strategies may work better than others. For example, Gerhart and Milkovich found that greater use of performance contingent pay was associated with better firm financial performance.

In this vein, future research on the possible firm performance consequences of $R \& D$ and compensation strategies would be useful. For example, do R\&D intensive firms that adopt a high base, high contingent pay profile outperform those that do not? Also, is such a compensation strategy more effective in High (versus low R\&D Intensive firms)? Based on self-reports of firm performance by compensation managers, the answer to these questions may be "yes" (Balkin \& Gomez-Mejia, 1987). However, evidence using objective accounting and financial measures is still lacking. In conducting such analyses, the choice of performance measure may be crucial (Abowd, 1990). Similarly, the time frame for performance may be very important. For example, if long-term growth in sales or shareholder wealth is the focus (e.g., in start-up firms), long-term incentive plans may be the most important key to success. In other words, future researchers of compensation design and strategy will need to continue to keep in mind that different firms have different objectives and face different competitive conditions, resulting perhaps in differences in the most effective compensation designs.

A recent study emphasizes the growing importance of these issues (Franko, 1989). In it, $R \& D$ intensity (as in the present study, defined in terms of $R \& D / s a l e s$ ) was one of 
the strongest correlates of subsequent sales growth performance of U.S. firms relative to international competition over 5-10 year periods. This finding reinforces the need for future research on how to insure that compensation strategies strengthen the impact of $R \& D$ intensity on competitiveness. 


\section{REFERENCES}

Abowd, J.M. (1990). Does performance-based managerial compensation affect corporate performance? Industrial and Labor Relations Review, 43, 52S-74S.

Acs, Z. \& Audretsch, D. (1988). Innovation in large and small firms: An empirical analysis. American Economic Review, 78, 678-690.

Allen, T.J. (1977) Managing the Flow of Technology, Cambridge, MA: MIT Press.

Balkin, D. B. \& Gomez-Mejia, L. R. (1984). Determinants of R and D compensation strategies in the high tech industry. Personnel Psychology, 37, 635-650.

Balkin, D. B. \& Gomez-Mejia, L. R. (1987). Toward a contingent theory of compensation strategy. Strategic Management Journal, $\underline{8}, 169-182$.

Beardsley, G. (1974). Rates of return from investments in innovation. Ph.D. Dissertation, University of Pennsylvania.

Bound, J., Cummins, C., Griliches, Z., Hall, B.H., \& Jaffe, A. Who does R\&D and who patents? In Z. Griliches (Ed.), R\&D, patents, and productivity. Chicago, Ill.: University of Chicago Press.

Brown, M. \& Swenson, R. (1988). Measuring R \& D productivity. Research Technology Management, July, 23-29.

Business Week (1989). Innovation in America: Special edition, June 16.

Cook, F. W. (1976) Strategic compensation. Frederick W. Cook Associates.

Dunlop, J.T. (1957). The task of contemporary wage theory. In G.W. Taylor and Frank C. Pierson (Eds.), New Concepts in Wage Determination. New York: McGraw-Hill. Dyer, L. \& Holder, G. W. (1989). A strategic perspective of human resource management. In L. Dyer (Ed.), Human resource management--Evolving roles and responsibilities. 
Washington, D.C.: Bureau of National Affairs, Volume 1.

Eisenhardt, K. M. (1988). Agency- and institutional-theory explanations: The case of retail sales compensation. Academy of Management Journal, 31 (3), 488-511.

Eisenhardt, K. M. (1989). Agency theory: An assessment and review. Academy of Management Review, 14, 57-74.

Ellig, B. R. (1981). Compensation elements: Market phase determines the mix. Compensation Review, Third Quarter, 30-38.

Fama, E. (1980). Agency problems and the theory of the firm. Journal of Political Economics, $\underline{88}, 288-307$.

Franko, L.G. (1989). Global corporate competition: Who's winning, who's losing, and the R\&D factor as one reason why. Strategic Management Journal, 10, 449-474.

Galbraith, J. (1982). Designing the innovative organization. Organizational Dynamics, Winter, 5-25.

Gambino, A. J. \& Gartenberg, M. (1979). Industrial R \& D management. New York, NY: National Association of Accountants.

Gerhart, B. \& Milkovich, G. T. Organizational differences in managerial compensation and financial performance. Working Paper \#89-11 (revised), Center for Advanced Human Resource Studies, Cornell University.

Gomez-Mejia, L. R. \& Welborne, T. M. (1988). Compensation strategy: An overview and future steps. Human Resource Planning, 11, 173-179.

Griliches, Z. (1986). Productivity, R \& D, and basic research at the firm level in the 1970s. American Economic Review, 76, 141-154. 
Hall, B.H., Cummins, C., Laderman, E.S., \& Mundy, J. (1988). The R\&D master file documentation. Technical working paper, No. 72, National Bureau of Economic Research, Cambridge, MA.

Hay Group (1986). Hay Compensation Information Center Data Base.

Jensen, M. \& Meckling W. H. (1976). Theory of the firm: Managerial behavior, Agency costs, and ownership structure. Journal of Financial Economics, $\underline{3}, 305-360$.

Kanter, R. M. (1989). When giants learn to dance: Mastering the challenges of strategy, management, and careers in the 1990s. New York: Simon and Schuster.

Kerr, J. \& Slocum, J. Jr. (1987). Managing corporate culture through reward systems. Academy of Management Executive, 1, 99-107.

Kleingartner, A. \& Anderson, K. S. (1987). Human Resource Management in High Technology Firms. Lexington, Mass.: Lexington Books.

Milkovich, G. T. (1988). A strategic perspective on compensation management. In K. Rowland \& G. Ferris (Eds.), Research in Personnel and Human Resources Management, 6, 263-288.

Radford Associates (1989). High technology compensation survey, 1988.

Ruch, W. A. (1980). Measuring knowledge worker productivity. Paper presented at Conference on Productivity Research: American Productivity Center, April 20-24.

Scarpello, V., Boulton, W. R., \& Hofer, C.W. (1986). Reintegrating R \& D into business strategy. The Journal of Business Strategy.

Scherer, F. M. (1984). Innovation and growth: Schumpeterian perspectives. Cambridge, MA: MIT Press. 
Schuster, J. R. (1987). Compensating engineers and scientists to help improve profits. Unpublished manuscript.

Scott, W. R. (1986). The adolescence of institutional theory. Administrative Science Quarterly, 32, 493-511.

Standard and Poor Corporation. (1988). COMPUSTAT. New York.

U.S. Bureau of Labor Statistics (1982). The impact of technology in five industries. Bulletin 2137. Washington, D.C. U.S. Printing Office.

Wyatt Group. (1989). ECS. Industry Group: High Technology. 


\section{FOOTNOTES}

1.We thank Tom Friedrich and Michael Sturman for their expert research assistance.

2.Gerhart and Milkovich (1989) found a correlation of approximately .50 between an empirically derived measure of relative pay level (using actual base and bonus payments for a sample of employees in each firm) and the reported pay level (measured using a method similar to that used by Balkin \& Gomez-Mejia, 1984). Although a correlation of this size is high enough to suggest convergence, it is sufficiently different from 1 to also indicate a significant potential for different results in using the two measures.

3.Our definitions of R\&D intensity have also been used in some previous literature (e.g., the Balkin \& Gomez-Mejia research) as indicators of whether a firm is high tech.

4.Agency theory breaks down when its basic premise does not hold. Asymmetry of information is based on separation of owners and managers. In small, new ventures or founder-controlled firms, the owners are more likely to possess the critical information; Therefore, monitoring costs of other managers may be less. Hence, in startup or smaller R\&D firms, the need to lead competitors' compensation may be less, since the owners themselves are likely to constitute key talent. Outcome based pay increases (bonus and long-term incentive) would, however, still be used to encourage managers to innovate.

5.In addition, judging by the p-values in Exhibit 6, a larger sample size (versus the reduced sample used for these analyses) would perhaps have yielded a reduced, but significant relation even using the yes/no measure of incentive eligibility. 
Exhibit 1

Rankings and Data Points for Those Firms Classified as Highly R\&D Intensive

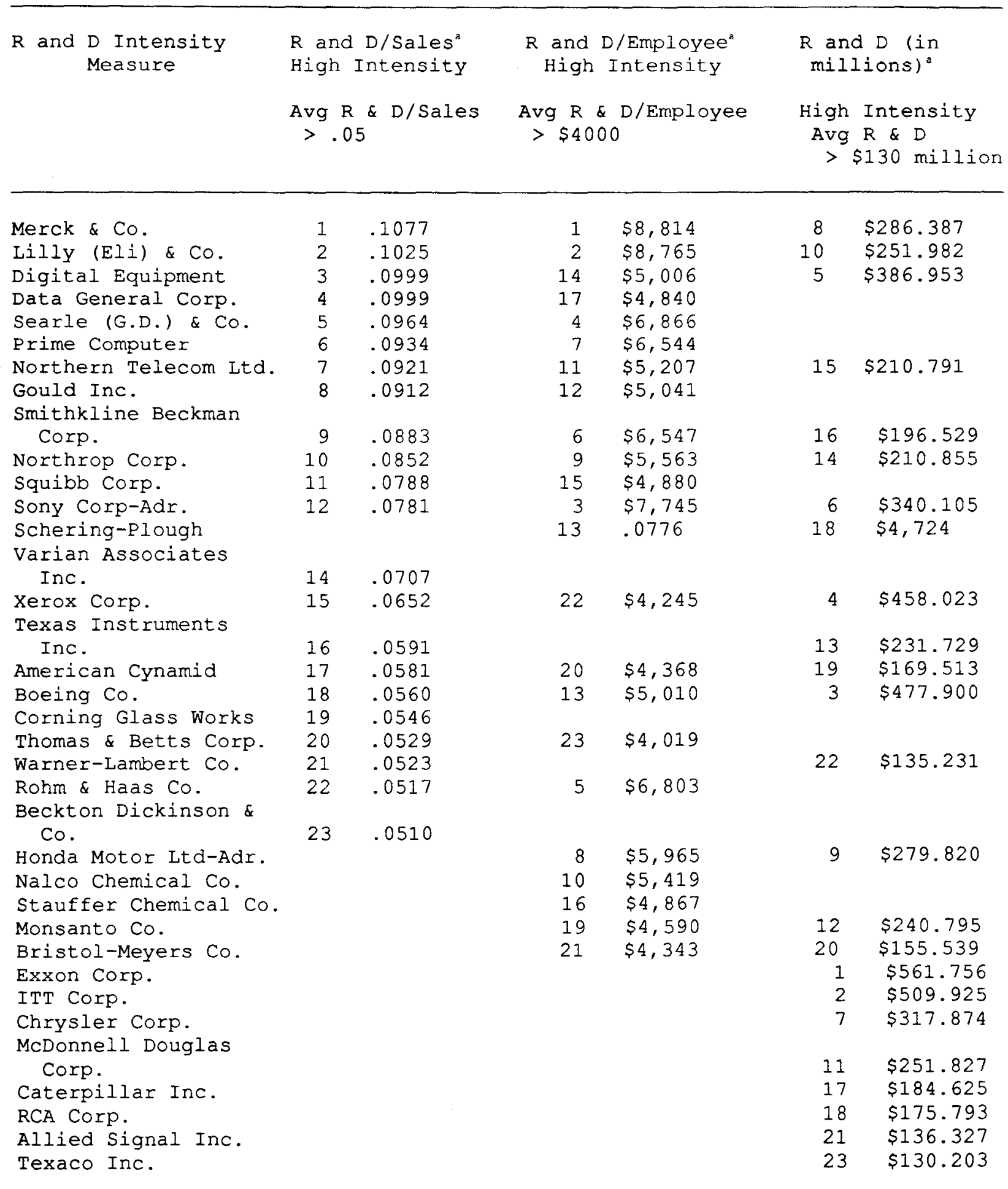

${ }^{a}$ Expressed in 1980 dollars. The C.P.I. adjustment multiplier to convert to 1988 dollars is 1.44 . 
Exhibit 2

Sample Summary Statistics, Firm Level

\begin{tabular}{|c|c|c|}
\hline VARIABLES & Mean & S.D. \\
\hline \multicolumn{3}{|l|}{ Company Data } \\
\hline Number of Employees & 32,218 & 36,968 \\
\hline Sales (millions) & $\$ 3,495$ & $\$ 8,465$ \\
\hline Income (millions) & 159 & 427 \\
\hline \multicolumn{3}{|l|}{$R$ and $D$ Intensity Data } \\
\hline $\mathrm{R}$ and $\mathrm{D} /$ Sales & .031 & .028 \\
\hline$R$ and $D /$ Employee & $\$ 2,330$ & $\$ 2,011$ \\
\hline$R$ and $D$ (millions) & 83 & 118 \\
\hline \multicolumn{3}{|l|}{ Compensation Data } \\
\hline Base Salary & $\$ 69,835$ & $\$ 11,905$ \\
\hline Bonus as a percent of Base & .20 & .18 \\
\hline $\begin{array}{l}\text { Long-Term Incentive } \\
\text { Eligibility }\end{array}$ & .60 & .18 \\
\hline Number of Firms & & 110 \\
\hline
\end{tabular}


Exhibit 3

Effect of $R \& D$ Intensity on Relative Base Salary

\begin{tabular}{|c|c|c|c|}
\hline Compensation Measure & $\begin{array}{c}\text { Relative } \\
\text { Base Salary }\end{array}$ & $\begin{array}{c}\text { Relative } \\
\text { Base Salary }\end{array}$ & $\begin{array}{c}\text { Relative } \\
\text { Base Salary }\end{array}$ \\
\hline \multicolumn{4}{|l|}{ Company Variables } \\
\hline Employees & $\begin{array}{l}.00200 * * *^{b} \\
(.00019)\end{array}$ & - & $\begin{array}{l}.00122 \star \star \star \\
(.00026)\end{array}$ \\
\hline Income & $\begin{array}{l}.00007 * \star \star \\
(.00002)\end{array}$ & $\begin{array}{l}.00010 \star \star \\
(.00004)\end{array}$ & 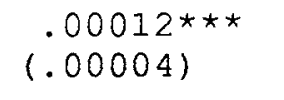 \\
\hline Sales & - & $\begin{array}{l}.0000026 \\
(.0000021)\end{array}$ & $\begin{array}{l}-.000005 \\
(.000002)\end{array}$ \\
\hline $\begin{array}{l}\text { Industry Control Variables } \\
R \text { and D Intensity }\end{array}$ & Yes & Yes & Yes \\
\hline $\mathrm{R}$ and $\mathrm{D} /$ Sales & $\begin{array}{l}1.391 * \star \star \\
(.2588)\end{array}$ & - & - \\
\hline $\mathrm{R}$ and $\mathrm{D} /$ Employee & - & $\begin{array}{l}.000027 \star \star \star \\
(.000004)\end{array}$ & - \\
\hline$R$ and $D$ & - & - & $\begin{array}{l}.00049 * \star \star \\
.00008\end{array}$ \\
\hline Intercept & $\begin{array}{l}-.1623+++ \\
(.0187)\end{array}$ & $\begin{array}{l}-.0920+++ \\
(.0173)\end{array}$ & $\begin{array}{l}-.1112+++ \\
(.0153)\end{array}$ \\
\hline Adjusted $\mathrm{R}^{2}$ & .47 & .37 & .49 \\
\hline Number of Observations & 448 & 448 & 448 \\
\hline Number of Firms & 110 & 110 & 110 \\
\hline
\end{tabular}

${ }^{2}$ Relative Base Salary is an organization average, adjusted for employee and job characteristics (see description in text).

${ }^{\mathrm{b}}$ Regression coefficient with standard error in parentheses

$\begin{array}{llr}\star & \mathrm{p}<.05, \text { one-tailed test } \quad+\mathrm{p}<.05, \text { two-tailed test } \\ \star \star & \mathrm{p}<.01 \text {, one-tailed test } \quad++\mathrm{p}<.01, \text { two-tailed test } \\ \star \star \star & \mathrm{p}<.001 \text {, one-tailed test } \quad+++\mathrm{p}<.001, \text { two-tailed test }\end{array}$


Exhibit 4

Effect of R\&D Intensity on Relative Bonus as a Percent of Base

\begin{tabular}{|c|c|c|c|}
\hline Compensation Measure & $\begin{array}{c}\text { Relative } \\
\text { Bonus as a Percent } \\
\text { of Base Salary }\end{array}$ & $\begin{array}{c}\text { Relative } \\
\text { Bonus as a Percent } \\
\text { of Base Salary }\end{array}$ & $\begin{array}{c}\text { Relative } \\
\text { Bonus as a Percent } \\
\text { of Base Salary }\end{array}$ \\
\hline \multicolumn{4}{|l|}{ Company Variables } \\
\hline Employees & $\begin{array}{c}-.000003^{b} \\
(.00015)\end{array}$ & - & $\begin{array}{l}.00016 \\
(.00021)\end{array}$ \\
\hline Income & $\begin{array}{l}.000026 * \\
(.000014)\end{array}$ & $\begin{array}{l}.00009 \pi \star \star \\
(.00003)\end{array}$ & $\begin{array}{l}.000104 \star \star \star \\
(.000003)\end{array}$ \\
\hline Sales & - & $\begin{array}{c}-.000004 * \star \\
(.0000015)\end{array}$ & $\begin{array}{l}-.0000052 \star \star \\
(.0000015)\end{array}$ \\
\hline Industry Control Variables & Yes & Yes & Yes \\
\hline \multicolumn{4}{|l|}{$R$ and $D$ Intensity } \\
\hline $\mathrm{R}$ and $\mathrm{D} /$ Sales & $\begin{array}{l}.3494^{\star} \\
(.2035)\end{array}$ & - & - \\
\hline $\mathrm{R}$ and $\mathrm{D} /$ Employee & - & $\begin{array}{l}.0000065 * * \\
(.0000027)\end{array}$ & - \\
\hline$R$ and $D$ & - & - & $\begin{array}{l}.000012 \\
.000066\end{array}$ \\
\hline Intercept & $\begin{array}{c}-.0409+t \\
(.0147)\end{array}$ & $\begin{array}{c}-.0383+t \\
(.0125)\end{array}$ & $\begin{array}{c}-.0294+ \\
(.0121)\end{array}$ \\
\hline Adjusted $\mathrm{R}^{2}$ & .032 & .057 & .046 \\
\hline Number of Observations & 448 & 448 & 448 \\
\hline Number of Firms & 110 & 110 & 110 \\
\hline
\end{tabular}

${ }^{2}$ Relative Base Salary is an organization average, adjusted for employee and job characteristics (see description in text).

${ }^{b}$ Regression coefficient with standard error in parentheses

* $\quad \mathrm{p}<.05$, one-tailed test

$\star \star \quad p<.01$, one-tailed test

$\star \star \star \quad \mathrm{p}<.001$, one-tailed test

$+p<.05$, two-tailed test
$++p<.01$, two-tailed test
$+++p<.001$, two-tailed test 
Exhibit 5 .

Effect of R\&D Intensity on Relative Long-Term Incentive Eligibility

\begin{tabular}{|c|c|c|c|}
\hline Compensation Measure & $\begin{array}{c}\text { Relative } \\
\text { Long-Term Incentive } \\
\text { Eligibility }\end{array}$ & $\begin{array}{c}\text { Relative } \\
\text { Long-Term Incentive } \\
\text { Eligibility }\end{array}$ & $\begin{array}{l}\text { Relative } \\
\text { Long-Term Incentive } \\
\text { Eligibility }\end{array}$ \\
\hline \multicolumn{4}{|l|}{ Company Variables } \\
\hline Employees & $\begin{array}{l}-.0021 * \star \star^{b} \\
(.00044)\end{array}$ & - & $\begin{array}{l}-.0033 \star \star \star * \\
(.0006)\end{array}$ \\
\hline Income & $\begin{array}{l}.00018 * * * \\
(.000040)\end{array}$ & $\begin{array}{l}.00022 * \star \\
(.000086)\end{array}$ & $\begin{array}{l}.00019 \star \\
(.00008)\end{array}$ \\
\hline Sales & - & $\begin{array}{l}-.000009 \star \\
(.0000046)\end{array}$ & $\begin{array}{l}-.000004 \\
(.000004)\end{array}$ \\
\hline $\begin{array}{l}\text { Industry Control Variables } \\
\mathrm{R} \text { and } \mathrm{D} \text { Intensity }\end{array}$ & Yes & Yes & Yes \\
\hline $\mathrm{R}$ and $\mathrm{D} /$ Sales & $\begin{array}{l}3.537 \star \star \star \\
(.5923)\end{array}$ & - & - \\
\hline$R$ and $D /$ Employee & - & $\begin{array}{l}.000031 * \star \star \\
(.000008)\end{array}$ & - \\
\hline$R$ and $D$ & - & - & $\begin{array}{l}.0007 * \star \star \\
.0002\end{array}$ \\
\hline Intercept & $\begin{array}{l}-.0007 \\
(.0427)\end{array}$ & $\begin{array}{l}-.0049 \\
(.0382)\end{array}$ & $\begin{array}{l}.1363+t+ \\
(.0364)\end{array}$ \\
\hline Adjusted $R^{2}$ & .151 & .083 & .107 \\
\hline Number of Observations & 448 & 448 & 448 \\
\hline Number of Firms & 110 & 110 & 110 \\
\hline
\end{tabular}

${ }^{2}$ Relative Base Salary is an organization average, adjusted for employee and job characteristics (see description in text).

${ }^{b}$ Regression coefficient with standard error in parentheses

* $\quad \mathrm{p}<.05$, one-tailed test

$\star * \quad \mathrm{p}<.01$, one-tailed test

$\star \star \star \mathrm{p}<.001$, one-tailed test $+p<.05$, two-tailed test

$++p<.01$, two-tailed test

$+++\mathrm{p}<.001$, two-tailed test 


\section{Figure Captions}

Figure 1. Average Base Salary for High Intensity and Other Firms Contrasted with Overall Sample Mean

Figure 2. Average Bonus as a Percent of Base for High Intensity and Other Firms

Figure 3. Average Long-Term Incentive Eligibility for High Intensity and Other Firms 

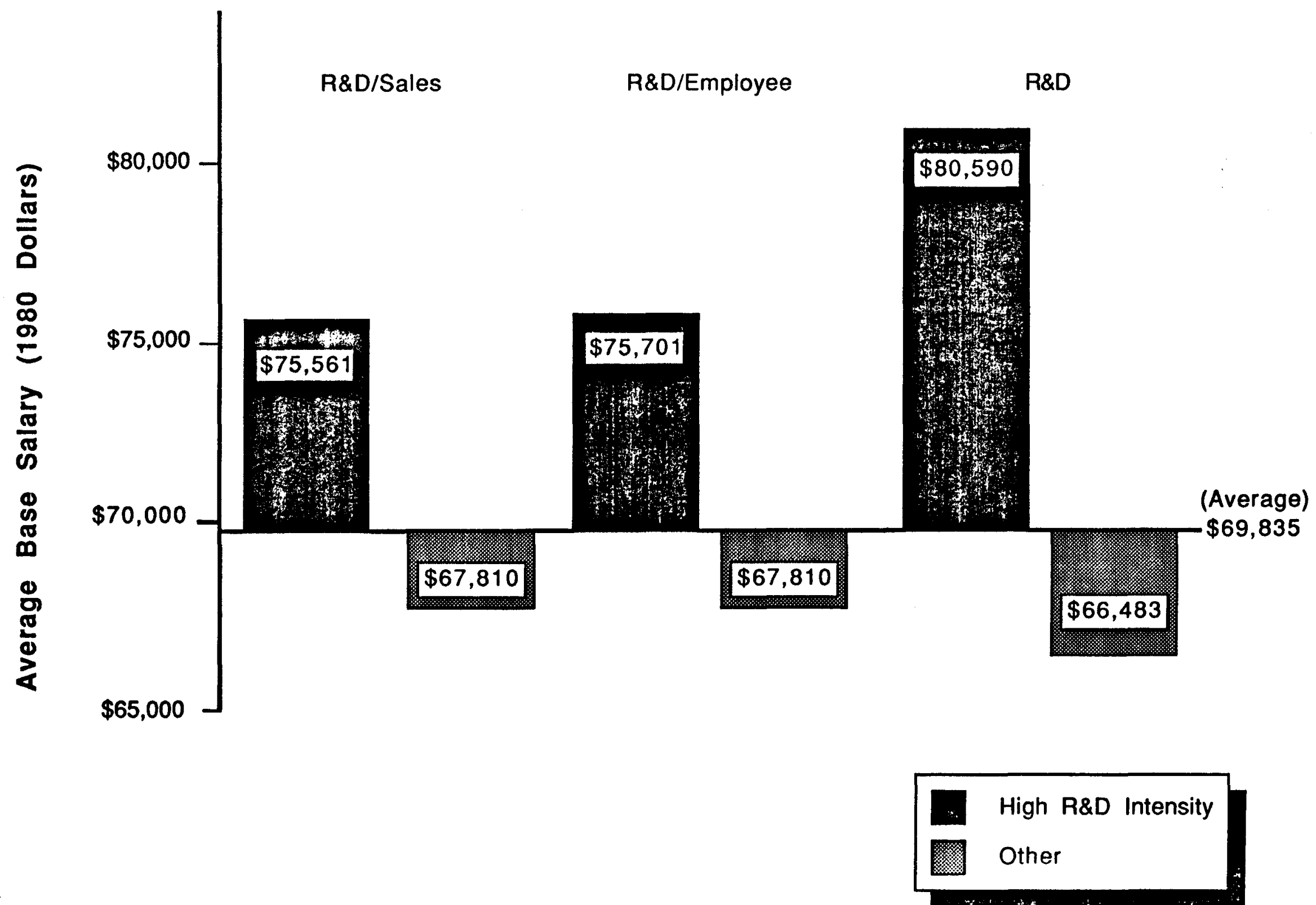


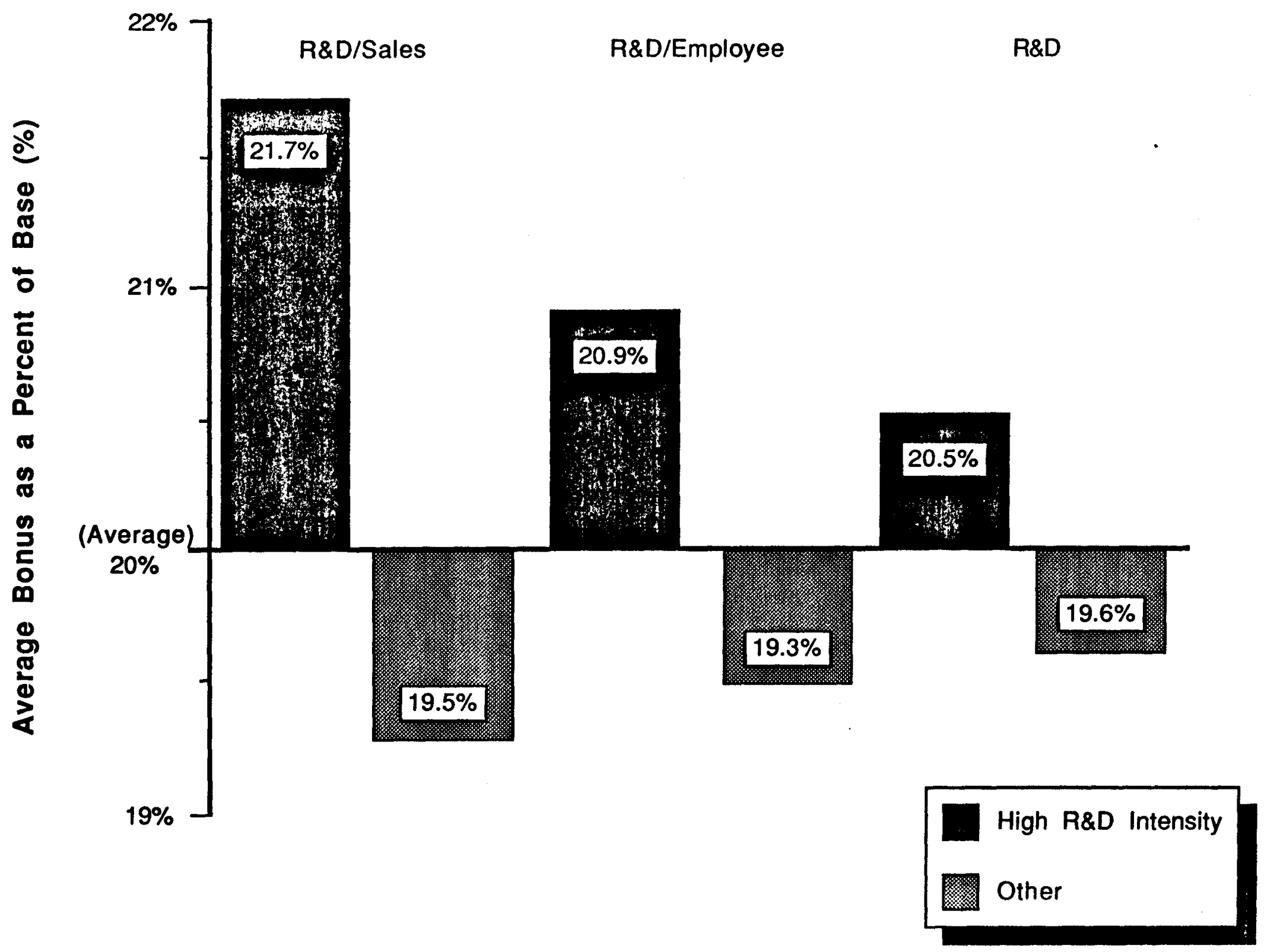




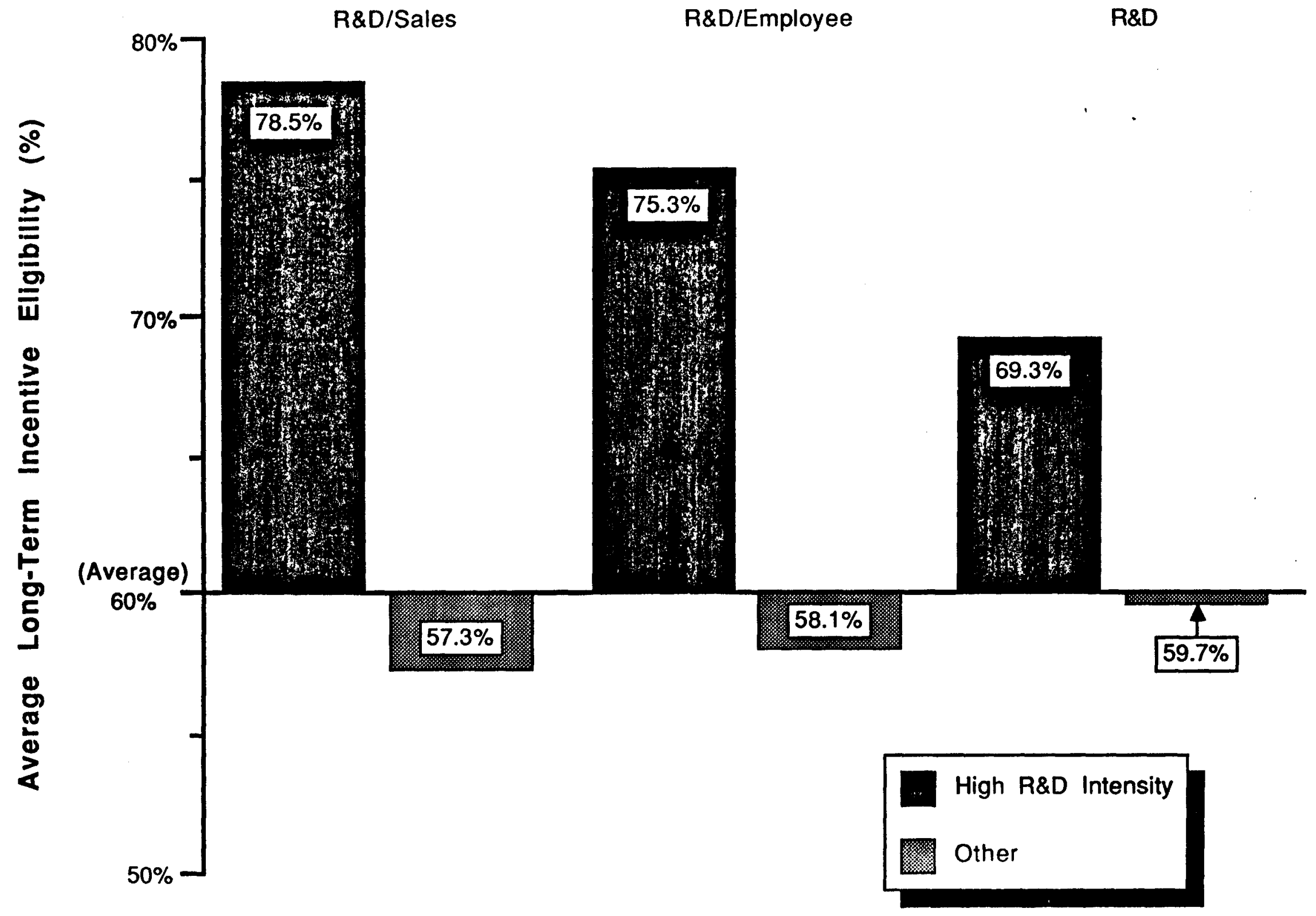

